\title{
The influence of structured supportive education on knowledge and attitude of parents with children suffering from upper respiratory tract infection to the envrionmental health
}

\author{
Dias Afrida Leolita ${ }^{1}$, Atika Dhiah Anggraeni ${ }^{2}$ \\ ${ }^{1}$ Students of Nursing Department, Faculty of Health Sciences, Universitas Muhammadiyah Purwokerto, Indonesia \\ ${ }^{2}$ Lecturer of Faculty of Health Science, Universitas Muhammadiyah Purwokerto, Indonesia
}

\begin{tabular}{l} 
ARTICLE INFO \\
\hline Article history: \\
Received:August 9, 2020 \\
Revised:August 20, 2020 \\
Accepted:August30, 2020
\end{tabular}

\section{Keywords:}

Knowledge, Attitude, Structured Supportive Education, Upper Respiratory Tract Infection (URTI)

\begin{abstract}
The upper respiratory tract infection (URTI) is possibly caused by the home environmental factors, individual factors and attitude factors. URTI is one major health problem occurring in, particularly children under 5 years old.

The structured supportive education is an interactive process to encourage learning efforts to add new knowledge, attitudes, and skills through both practical strengthening and exceptional experiences. The purpose of this research is to figure out the effect of structured supportive education on knowledge and attitudes of mothers with children experiencing theupper respiratory tract infection (URTI). This research employed as qualitative method with a quasi-experimental design and pretestposttest one group design approach. The research result indicated that structured supportive education affected knowledge and attitude with thep-valueof 0.046. It is expected that the result of this research is possibly used as one treatment intervention media to improve the knowledge and attitude of parents with children experiencing theupper respiratory tract infection (URTI). Besed on the results of research on Structured Supportive Education, it is significantly more influential in improving the knowledge and attitudes of parents.
\end{abstract}

This work is licensed under a Creative Commons Attribution 4.0 International License.

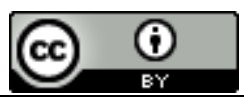

\section{Corresponding Author:}

Dias Afrida Leolita,

Department of Nursing, Faculty of Health Sciences,

Universitas Muhammadiyah Purwokerto,

Suparjo Rustam Road KM 7, Purwokerto, 53186, Indonesia.

Email: diasafrida2@gmail.com

\section{INTRODUCTION}

ARI (Acute Respiratory Infection) is the main cause of morbidity and mortality of infectious diseases in the world. The mortality rate for ARI reaches 4.25 million every year in the world [1]. The prevention of ARI in children under five according to the characteristics, Riskesdes, 2018 ARI patients in children under five throughout Indonesia is $12.8 \%$ or around 93,620 . The prevalence of ARI in children under five in Central Java province occupies number 8 in Indonesia in 2018 with 10,551 people with ARI in children under five [2]. The Health Office of Banyumas Regency, the ARI division, stated that the discovery of ARI patients with the penemonomia class in 2018 was 2,173 children with a target of 5,945 children under five.

According to the Lawrence Green concept, the health of a person or society is influenced by 2 main factors, namely behavior causes, knowledge, attitudes, beliefs, non-behavior causes, supporting factors (health service facilities), and driving factors (attitudesand behavior of health workers) [3]. Increased knowledge is not absolutely derived from formal education, but can also be obtained from non-formal education. One of them is Structured Supportive Education, which is an interactive process that encourages learning, and learning is an effort to add new knowledge, attitudes, and skills through strengthening certain practices and experiences. The purpose of the study was to determine the effect of structured supportive education methods on the knowledge and attitudes of parents who have children with ARI about environmental health. 


\section{RESEARCH METHOD}

The design used in this study used a quasi-experimental design with a pre-post test one group design approach. The sampling technique used in this study was a random sampling technique that amounts to 30 respondents. Data collection using a questionnaire and data analysis using Paired t test. This research has passed the KPEK / UMP / 9 / II / 2020 Research Ethics license. This research was conducted in June 2020 at Puskesmas Sokaraja 1.

\section{RESULTS AND DISCUSSIONS}

This research was conducted in June 2020 at Puskesmas Sokaraja 1 with the title "The Effect of Structured Supportive Education on Parents' Knowledge and Attitudes who Have Children with ARI about Environmental Health" with a total of 30 respondents. The results of the study were analyzed and presented in tabular form.

Table 1. Distributor of Respondents Characteristics ( $\mathrm{n}=30)$

\begin{tabular}{lcc}
\hline Characteristics & Frequency & Percentage \\
\hline Gender & 29 & $96,7 \%$ \\
Women & 1 & $3,3 \%$ \\
Man & & \\
Education & 2 & $6,7 \%$ \\
$\quad$ Primary school & 23 & $76,7 \%$ \\
Secondary school & 5 & $16,7 \%$ \\
College & & \\
Profession & 22 & $73,3 \%$ \\
Housewife & 6 & $20,0 \%$ \\
Private employees & 2 & $6,7 \%$ \\
Businessman & &
\end{tabular}

Based on Table 1 above, it can be concluded that the frequency distribution of the respondent characteristics at EST is mostly female respondents with the total of 29 respondents $(96.7 \%)$. With the level of education at EST most of the high school students are 23 respondents (76.7\%). And the rest of 22 respondents did not work (73.3\%).

Table 2. Knowledge and attitude of parents with children experiencing upper respiratory tract infection

\begin{tabular}{lcccc} 
Variable & Mean & SD & SE & p-value \\
\hline $\begin{array}{l}\text { Knowledge } \\
\text { Before }\end{array}$ & 40,90 & 1,596 & 0,291 & 0,001 \\
$\quad$ After & 45,27 & 2,881 & 0,526 & \\
$\begin{array}{l}\text { Attitude } \\
\quad \text { Before } \\
\text { After }\end{array}$ & 24,80 & 1,377 & 0,251 & 0,001 \\
\hline
\end{tabular}

Based on the research results in the table above, the average value of the respondents' knowledge before being given Structured Supportive Education for Parents was 40.90 and after being given was 45.27. The average difference before being given education was 1.596 and after being given 2.881, while the Standard Error value before being given was 0.291 after being given was 0.526, and the p-value was 0.001. As for the attitude of Structured Supportive Education before being given was 24.80 and after being given was 28.03. The average difference before being given was 1.377 and after being given was 2.219, while the Standard Error value before being given was 0.251 as and after being given 0.405 , and the p-value was 0.001 .

Based on the results of this study, it shows that there is an effect of Structured Supportive Education on the knowledge and attitudes of parents who have children with ARI about environmental health. The results of this study are in line with the research which states that the provision of Structured Supportive Education about pre-operative anxiety with the results of Structured Supportive Education is very helpful to improve patients' knowledge. Other results of the research show that supportive educative significantly improved the survivors' positive attitudes about physical activity. This situation can be caused by the supportive educative program provided, one of which is guiding, in guiding there are discussions and alternative solutions to problems, especially solving problems with lack of physical activity. The existence of problem-solving discussions can increase the survivors' confidence in alternative solutions to existing problems, so the supportive educative given can increase a positive attitude towards physical activity [4]. The results of this study are consistent with studies that found that supportive education has a positive effect on self-care attitudes in patients with diabetic foot ulcers and heart failure [5]. 
Supportive education conducted on Structured Supportive Rducation respondents started by welcoming to fill in the pre-test questionnaire first, then the respondent swereprovide with material about environmental health 3 times for 3 consecutive days before finally filling out the questionnaire for the post test. Researchers conducted a Healthy Home Index assessment to measure the effect of Structured Supportive Education by observing the respondent's house. Structured Supportive Education is superior to other education because there is developing health behavior which ultimately allows respondents to be responsible for their own health and there are 3 techniques, namely support, guidance, and teaching where the information provided has been well structured in order to improve the understanding of the respondents. The material is delivered 3 times with the same material for 3 consecutive days, it is expectedto have a better effect than the one time education done.

Structured supportive education is the design of health education and training that is planned and targeted to achieve patient understanding in improving optimal health that has advantages in the Nursing system theory, namely a health service system that facilitates the fulfilment of the needsof self-reliance providing it therapeutically in according with the level of ability, namely The wholly compensatory nursing system, given to patients with high dependence. The partially compensatory nursing system, given to patients with moderate dependence, and The support educative nursing system given to patients with mild discontinuation or dependence [6]. Structured supportive education consists of 3 techniques, namely support, guidance, and teaching. Guidance is an assistance given by one person to another in making choices and adjustments in solving problems with the aim of helping to foster a person's freedom and ability to become aresponsible individual for themselves. ${ }^{[6]}$

\section{CONCLUSION}

Based on the results of research on Structured Supportive Education, it is significantly more influential in improving the knowledge and attitudes of parents.

\section{REFERENCES}

[1] Najmah, Epidemiologi Penyakit Menular, Jakarta: Trans Info Media, 2016.

[2] Riset kesehatan Dasar (Riskesdes), "Badan penelitian dan pengembangan kesehatan RI tahun 2018 ," 2018. [Online]. Available: http://www.depkes.go.id/resources/download/infoterkini/materirakorpop_2018/Hasil\%20Riskesdes\%202018.pdf. [Accessed Oktober 2019].

[3] Notoatmodjo, Promosi Kesehatandan Perilaku Kesehatan, Jakarta: PT. Rineka Cipta, 2012.

[4] Darmansah, Nursalam and Suharto, "Efektifitas supportive educative terhadap peningktan self regulation, self efficacy dan, self care agency dalam control glokemik penderita diabetes militustipe 2," Jurn al Ners, vol. 8, pp. 254-270, 2013.

[5] P. M. Shahrbabaki, J. Farokhzaidian and Hasanaba, "Effect of Self-care Education on Patien Knowlage and Performance with Heart Failure," Procedia-Social and Behavioral Scrences, vol. 31, pp. 918-922, 2012.

[6] Qomariah, "Pengaruh Supportive Edukativ Nutrisi Pada Pasien Gastroparesis Diabetik dan KeluargaPendekatan Teori Adaptasi Roy," Universitas Airlangga, Surabaya, 2014. 